\title{
Moral Hazard Assessment in State-subsidized Renewable Energy Investments
}

\author{
Olivér Hortay ${ }^{1 *}$ \\ 1 Department of Environmental Economics, Faculty of Economic and Social Sciences, Budapest University of Technology and \\ Economics, H-1521 Budapest, P.O.B. 91, Hungary \\ * Corresponding author, e-mail: hortay@eik.bme.hu
}

Received: 06 April 2018, Accepted: 30 August 2018, Published online: 28 January 2019

\begin{abstract}
This paper presents the impact of state subsidy programs on moral hazard in renewable energy investments. The purpose of the research is to build a theoretical model which is able to handle the borrower's behavior under asymmetric information circumstances, thus creating a new aspect in the debate about the choice of the financially ideal incentive structure. The general conclusion of the article is that technology based subsidy mechanisms which provide great protection to the investing companies (ceteris paribus), increase information asymmetry and agency costs. While these systems improve predictability of revenues, they block effective lending or otherwise, the market dependent subsidies moderate the moral hazard, which reduce the risk of fluctuating market prices. Keywords
\end{abstract}

contract theory, asymmetric information, renewable energy investments, state subsidies

\section{Introduction}

In the last decades, the member states of the European Union (EU) have devoted - in a different system and logic - a lot of resources to the spread of renewable energy sources (RES). The idea behind state subsidies is that RES-based electricity (RES-E) production has social and environmental benefits, which are not reflected in market prices and that the internalization of such effects requires market intervention. This activity has been reinforced by the widely accepted expectation that the EU can benefit from the experiences and emerging good practices it gains by firstly moving in the direction of renewables, through artificially increasing their share in the energy mix and ultimately achieving a global advantage (Verbruggen and Lauber, 2012). The European Parliament and the Council have also quickly recognized the need for coordinated action by the Member States to achieve these changes and have therefore issued a special directive on the propagation of renewable energies (European Parliament and Council, 2001). The European countries have relatively freely shaped their incentives thus different types of schemes have evolved (Ackerman et al., 2001).

Price subsidies can be divided into two main categories: feed-in tariff (FIT) and feed-in premium (FIP). In the FIT systems, producers sell electricity at regulated, constant (partly inflation-corrected) price, to a balancing group designated by the authority. The balancing group sells energy on the market and receives compensation for its loss. In the FIP systems, the producers sell electricity on the market and receive a premium over the sales price. Based on the logic of the premium calculation, FIP systems can be classified into other categories. Among them, this study analyses the fixed premium, the floating premium and multiplier premium subsidies.

However, as pointed out by most experts, mostly feed-in tariff systems were deployed, which is considered to be the most effective (Butler and Neuhoff, 2008; Fouquet and Johansson, 2008; International Energy Agency, 2008; Klein et al., 2008; Lipp, 2007; Mendonça, 2007; Stern, 2006) in order to increase the market share of renewable technologies. Apart from the internalization of external costs, the achievement of renewable capacity objectives for each priority year has also appeared as an additional motivation (European Parliament and Council, 2009).

While subsidy systems had contributed significantly to the growth of RES capacities (Nicolini and Tavoni, 2017), in 2014, the European Commission issued a new guideline that approached RES-E incentives from a new perspective (European Commission, 2014). The document 
emphasized the importance of developing financial incentives (Dinica, 2006; Verbruggen and Lauber, 2012) and they responded to recent trends, such as the drastically decreasing cost of RES-E production and emergence of new technologies (Dinica, 2011). The main lesson was that there is no longer a need for a strong market defense for RES producers at the expense of other players because it seriously distorts the market and reduces competitiveness. RES technologies need to be launched on the market to compete in the near future with traditional producers (Giacomarra and Bono, 2015; Huntington et al., 2017). According to the new guideline, from January 1, 2017, the FIT system should be replaced by a feed-in premium structure (except for low installed capacity and demonstration projects), which can be allocated by the Member States after a tendering procedure (European Commission, 2014). Therefore, the effects of the conversion that the incentives brought about can be expected to be twofold: on the one hand, the greater integration of RES producers (Boscan and Poudineh, 2016; Klein et al., 2008; Lipp, 2007) and, on the other hand, the increase of investor risks (Mendonça, 2007). Consequently, under the new support environment, financing conditions will change and unless the tenders will result in higher prices than the previous FIT, - according to simple business logic - higher risks will be associated with lower expected returns. In addition to that, with decreasing predictability, an another factor appears: by providing less public protection to RES operators, a selection mechanism may be launched in which those will survive who find better solutions for RES-E sales. Moreover, what the most important is in the context of this paper that sales performances provides additional signals to financiers, reducing the information gap between the two stakeholders. To help decision-makers predict how market players will respond to the introduced support system, it is necessary to understand the motivations of these participants.

Many empirical results show that the capital market is not cleared through interest rate adjustment and the capital allocation between investments does not reach the social optimum (Baker et al., 1988; Bebchuk and Fried, 2003; Bertrand and Mullainathan, 2000; Hall and Liebman, 1998). One of the main equilibrium explanations of this phenomenon is that the reason for distortion is the systematic presence of information asymmetry between investors and entrepreneurs (Mankiw, 2004), with particular regard to its two types: adverse selection and moral hazard. There is no consensus in the literature regarding the impact of state subsidies on the appearance of the two factors: while some authors suggest that subsidies may partly be a solution for the adverse selection problem (Kleer, 2010; Takalo and Tanayama, 2010), others have come to the conclusion that state interventions present unrealistic incentives to firms (Chaney and Thakor, 1985; Hirsch, 2006; Keuschnigg and Nielsen, 2001; Schertler, 2000; 2002a; 2002b). In the past, many authors have generalized the moral hazard between private participants in corporate financial models (Csóka et al., 2015; Grossman and Hart, 1983; Hart and Moore, 1998; Holmstrom and Tirole, 1997; Laffont and Tirole, 1988; Sappington, 1983; Shavell, 1979; Tirole, 2006), but - as benefits of subsidies are mostly generated at the social level - it is also worthwhile to take into account the public impacts (Berlinger et al., 2017).

This article presents borrower's and lender's behavior in a contract theory approach to each RES-E subsidy system, so to say how state interventions affect the information asymmetry between the two participants and thus the social benefit of the project. The main result of the research is that all subsidies increase the social benefits and the payment of the entrepreneur and the investor as well, but each system to a different extent: the information asymmetry decreases in the more moderate state protection systems and thus the social benefits of the project increases.

Section 2 presents the benchmark model for the comparison method, Section 3 discusses separately how each subsidy system modifies the basic model, Section 4 summarizes the results and finally Section 5 presents the conclusions and their policy implications.

\section{Benchmark model ${ }^{1}$}

The benchmark model can be basically given as a combination of two previously published papers. Holmstrom and Tirole (1997) have built a scalable, constant rate of return model for two participants (entrepreneur and investor), in which initial investment $I$ is needed to realize the project $(I>0$ ), but the entrepreneur has only initial asset $A$ (where $I>A>0$ ), so there is a need for an investor to finance the remaining $(F=I-A)$ amount. The main problem is that during the operation, the entrepreneur will have more information about the company than the investor and therefore it will be harder to judge the correlation of success or failures and the effort on the entrepreneur's side, as well as other external effects of the market. For illustrating

1 The benchmark model based on Berlinger et al. (2017) nonrefundable ex-ante subsidy model. 
the phenomenon: the efficiency of a biomass power plant is influenced high extend by the price and quality of the knuckled wood. Generally, biomass is not economically remotely transported, so fuel is purchased from local sources. In addition, the quality of knuckled wood is influenced by a number of factors, and their continuous monitoring requires a huge effort from the entrepreneur. But it is not always possible to check directly whether high fuel costs (or low fuel quality) are due to the fact that prices are actually high or the entrepreneur has not exerted sufficient effort to conduct less expensive purchases. Such a risk may be affected by state intervention, so the model needs to be expanded with the subsidy $S$ and the externalities generated $E$ by the investment (Greenwald and Stiglitz, 1986). Berlinger et al. (2017) expands the previous model with a third (state) participant and takes into account external influences, hence maximizing social as well as corporate benefits.

\subsection{Assumptions}

The project consists of a single period: in $t=0$ the investment is realized, and in $t=1$ the participants share the profit. There are two possible outcomes of the model: success with probability $p$ and failure with probability $1-p$ (where $0 \leq p \leq 1$ ). As the entrepreneur's behavior influences the success of the project (and the investor cannot directly observe it), probabilities can be shaped in two ways: when the entrepreneur makes a high effort, the probability $p=p_{H}$ or when the entrepreneur makes a low effort, the probability $p=p_{L}$ (where $p_{H}>p_{L}$ ). There are three types of benefits in the project and all three depend on the size of the investment:

- The positive externality $E$ (for example emission reduction, job creation or other external benefits from RES-E investment) justifies the state subsidy ( $E$ varies proportionally with the size of $I$, and $E I>0)$. This is independent of the financial success of the project, so it appears with the realization of the investment, and it increases social welfare.

- The $R I$ is the return of the investment (where $R>1$ ). $R I$ will only be realized if the project is successful (with probability $p$ ). The $R I$ is shared between the entrepreneur and the investor: $R I=R_{e}+R_{i}$, where $R_{e}$ is the entrepreneur's and $R_{i}$ is the investor's return (in case of failure, the entrepreneur and the investor do not get paid).

- The entrepreneur's private benefit $B$ arises (and also varies with the size of $I$ ) if he or she makes a low effort $(B I>0)$.
In order for the model to focus solely on moral hazard, it assumes risk neutrality for all participants, so decisions are only influenced by the expected values. Assume that the time value of money is zero consequently, there is no need to discount between periods. The market for investors is perfectly competitive, so their expected returns are zero, hence all amount above zero net present value will be realized on the entrepreneur's end. Participants have limited liability, thus they can only lose as much money as they have invested.

The third participant is the state, which, in order to compensate for the externalities realized by the project, supports the investment by amount $S$. The subsidy contract is concluded between the state and the entrepreneur before agreeing with the investor. The timing of the project is shown in Fig. 1.

Based on these parameters, the social welfare $(W)$ can be written as the sum of private and public utilities (net present values). The objective is to maximize social welfare:

$\max W=\max p_{H} R I+E I-I$.

The problem will be relevant if the agent's low effort can cause a loss to somebody. The relevance of the moral hazard assumption can be described as Eq. (2):

$p_{H} R I+E I-I>0>p_{L} R I+E I+B I-I$.

Finally, in the case of renewable power plant projects, we have the following specific assumptions:

- The entrepreneur can influence its operating costs and sales prices through its behavior so - keeping the previous example - if the management of a biomass power plant exerts high efforts, it can reduce its expenditures (more efficient fuel procurement, well allocated resources etc.) and increase its revenue (selling its electricity at a higher price).

- In case of failure (with probability $1-p$ ), the power plant will be built and operated during the period (the grant will be disbursed as described below and the external effects will also be realized), however, revenues and costs do not allow the entrepreneur and the investor to earn money $\left(R_{e}=R_{i}=0\right)$.

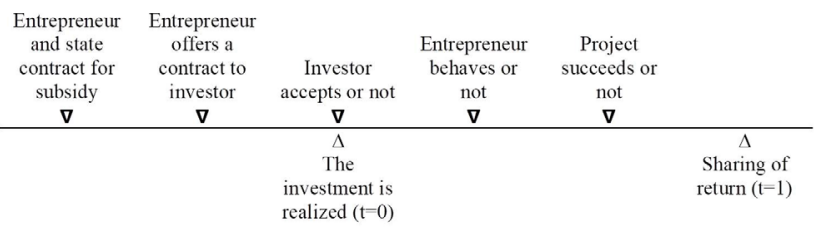

Fig. 1 The timing of the project. Source: Berlinger et al. (2017) 
- The examined period is the same as the duration time of the subsidy and the lifetime of the power plant, i.e. at $t=0$ the investment is realized and at $t=1$ the profits generated during the lifetime of the power plant are distributed among participants.

- The state is able to forecast and price the externalities associated with the project, based on which it determines the level of the subsidy.

\subsection{Methodology}

The problem focuses on the selection of the right type of contract: the players have to decide in order to reach the social optimum. The contract design basically addresses three questions: what is the optimal size of $I$, the optimal size of $S$ and how much are the entrepreneur's and the investor's payments $\left(R_{e}, R_{i}\right)$. This can be achieved by optimizing the decision parameters $\left(F, I, R_{e}, R_{i}\right)$, while taking into account the exogenous parameters $(R, B, A$, $\left.p_{H}, p_{L}\right)$. According to the assumption that the entrepreneur maximizes its own profit and there is perfect competition among investors, previous equations give the objective function of the optimization problem of the entrepreneur $\left(\mathrm{Obj}_{\mathrm{e}}\right)$ as Eq. (3):

$\operatorname{Obj}_{\mathrm{e}}: \max \left(p_{H} R I-p_{H} R_{i}-A\right)$.

A possible set of solutions to the problem is restricted by additional conditions. The financier will be interested in concluding a contract that motivates the entrepreneur to exert high effort, identifying the incentive constraint of the entrepreneur $\left(\mathrm{IC}_{\mathrm{e}}\right)$ :

$\begin{aligned} \mathrm{IC}_{\mathrm{e}}: & p_{H} R_{e} \geq p_{L} R_{e}+B I \\ & R_{e} \geq B I /\left(p_{H}-p_{L}\right)\end{aligned}$

The investor will only capitalize on the project if the expected value of the payment is greater than the capital. This can be used to prescribe the participation constraint of the investor $\left(\mathrm{PC}_{\mathrm{i}}\right)$ :

$\mathrm{PC}_{\mathrm{i}}: p_{H} R_{i} \geq F$.

Finally, the budget constraints $(\mathrm{BC})$ must be taken into account, which will appear in $t=0\left(\mathrm{BC}_{0}\right)$, and in $t=1\left(\mathrm{BC}_{1}\right)$ :

$\mathrm{BC}_{0}: A+F+S-I \geq 0$

$\mathrm{BC}_{1}: R I-R_{e}-R_{i} \geq 0$.

The optimization problem can be solved by the KuhnTucker method, for which the Lagrange equation can be written, which will obviously have one solution (the lambdas are positive and the constraints are binding):

$$
\begin{aligned}
& \mathcal{L}=p_{H} R I-p_{H} R_{i}-A-\lambda_{1}\left(B I /\left(p_{H}-p_{L}\right)-R_{e}\right) \\
& -\lambda_{2}\left(F-p_{H} R_{i}\right)-\lambda_{3}(I-A-F-S)-\lambda_{4}\left(R_{e}+R_{i}-R I\right) .
\end{aligned}
$$

The level of subsidy will be determined by the state as a solution to an optimization problem whose goal is to maximize social welfare ergo the objective function is Eq. (1). It is easy to see that the state will only support the project if the externalities exceed the subsidy, thus this will be the only participation constraint of the state $\left(\mathrm{PC}_{\mathrm{S}}\right)$ :

$\mathrm{PC}_{\mathrm{S}}: E I-S \geq 0$.

\subsection{Results of the benchmark model}

After solving the two multivariate optimization problems, the decision parameters can be deduced by simple algebraic transformations, which are as follows:

- the optimum size of the investment is:

$I=A /\left(1-\rho_{0}-E\right)$,

where $p_{0}$ is the maximum income pledged by the entrepreneur without the moral hazard being incurred:

$\rho_{0}=R-B /\left(p_{H}-p_{L}\right)$,

- the level of state subsidy is:

$S=A E /\left(1-\rho_{0}-E\right)$,

- the expected share of entrepreneur is:

$R_{e}=\left((A+S)\left(p_{H} R-\rho_{0}\right)\right) /\left(p_{H}\left(1-\rho_{0}\right)\right)$,

- the expected share of investor is:

$R_{i}=\left(\rho_{0}(A+S)\right) /\left(p_{H}\left(1-\rho_{0}\right)\right)$

- and the social welfare is:

$W=\left(A\left(p_{H} R+E-1\right)\right) /\left(1-\rho_{0}-E\right)$.

According to Berlinger et al. (2017), the benchmark model allows us to consider state subsidies in analyzing information asymmetry. The model therefore shows that nonrefundable subsidies reduce moral hazard and have a positive impact both on project size and on social welfare. Based on these, it may be worth to the state to support RES-E investments, but as the types of renewable subsidies differ from the classic nonrefundable investment subsidies, it is useful to implement the benchmark model for each type of subsidy. 


\section{Contract design in the subsidy systems}

This section provides a separate description of the optimization tasks that can be written for different types of RES-E subsidy systems for moral hazard.

\subsection{Optimal contract design in FIT system}

The essence of the FIT systems is that the recipient gets the generated electricity from a producer within a fixed time interval at a fixed price. The tariff is determined by the regulator, taking into account production costs and optionally differentiating the prices according to technology, size, type of energy or geographic location (Fouquet and Johansson, 2008; Klein et al., 2008; Mendonça, 2007). During the subsidy period, the FIT can be fixed (constant during the subsidy period), inflation following (the price of the subscription is continuously or periodically inflationary during the subsidy period) or front-end loaded (two or more fixed tariffs at different levels in the period divisible) (Couture and Gagnon, 2010). However, the categories of the FIT system do not need to be modelled separately because participants are risk-neutral, so this article discusses the simplest, fixed FIT system, in which, payments are constant over the period (Fig. 2).

In the FIT system, the power plant does not have a sales risk because the total revenue is provided by the state (SI) (Lipp, 2007). The level of state aid will be determined by two things: the externalities of the project $(E I)$ and the expected selling price of the received electricity $(M I)$. In this case, there is no information asymmetry on the revenue side, the investor knows in advance what the production capacity of the power plant is and how much the selling price will be. In the case of operating

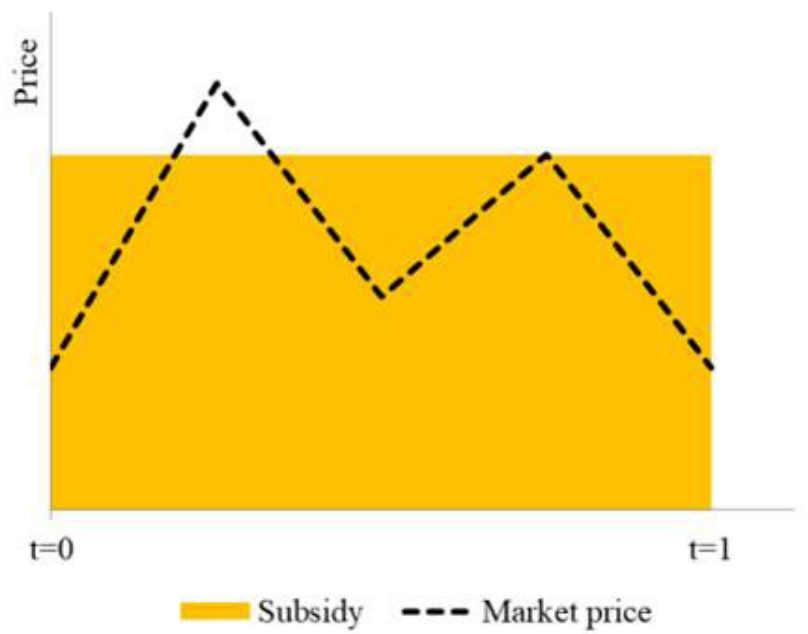

Fig. 2 In the FIT system, the total revenue is independent of the market prices. expenditures, the agency costs appear because the effort of the entrepreneur cannot be predicted and controlled perfectly. The expected operational expenditure incurred during the project is indicated by $\mathrm{CI}$, which is to be corrected by $d_{H}$ if the entrepreneur makes high effort (with probability $p_{H}$ ), and by $d_{L}$ if not (with probability $p_{L}$ ), where $d_{H}<1<d_{L}$, not observable parameters. The income generated by the project is shared by the entrepreneur and the investor $\left(S I-d_{H} C I=R_{e}+R_{i}\right)$. The relevance of the moral hazard assumption is modified:

$M I+E I-d_{H} C I-I>0>M I+E I-d_{L} C I+B I-I$ $M+E-d_{H} C>1>M+E-d_{L} C+B$.

In determining the extent of the subsidy, the state takes into account, in addition to the external effects, how much revenue it will be able to get through reselling the electricity received on the market $(M I)$, thus changing the state budget constraint. The objective functions and constraints of the optimization problem for the FIT system are given in Table 1.

\subsection{Optimal contract design in FIP systems}

The basic concept of the FIP systems is that the producer sells the electricity on the market so that it also takes sales risks beyond the operational risks and therefore the information asymmetry between the entrepreneur and the financier is influenced by the revenue side. The FIP definition, like the FIT system, may also differ depending on the technology, energy resource, size, location, and may incorporate seasonal changes, but they will no longer affect the model. FIP systems can be categorized according to the logic of premium formation: distinguishing between fixed (market-independent) and variable (market-dependent) subsidies (Couture and Gagnon, 2010). The subsection first implements the benchmark model framework on the fixed premium system, then details the reference price variable and the proportional variable premium systems.

Table 1 Optimization problem for FIT system

\begin{tabular}{|c|c|c|}
\hline $\mathrm{Obj}_{\mathrm{e}}$ & $\begin{array}{l}\text { Objective function of } \\
\text { entrepreneur }\end{array}$ & $\max \left(S I-d_{H} C I-p_{H} R_{i}-A\right)$ \\
\hline $\mathrm{IC}_{\mathrm{e}}$ & $\begin{array}{l}\text { Incentive constraint of } \\
\text { entrepreneur }\end{array}$ & $R_{e}-B I /\left(p_{H}-p_{L}\right) \geq 0$ \\
\hline $\mathrm{PC}_{\mathrm{i}}$ & $\begin{array}{l}\text { Participation constraint } \\
\text { of investor }\end{array}$ & $p_{H} R_{i}-F \geq 0$ \\
\hline $\mathrm{BC}_{0}$ & Budget constraint $(t=0)$ & $A+F-I \geq 0$ \\
\hline $\mathrm{BC}_{1}$ & Budget constraint $(t=1)$ & $S I-d_{H} C I-R_{e}-R_{i} \geq 0$ \\
\hline $\mathrm{PC}_{\mathrm{S}}$ & $\begin{array}{l}\text { Participation constraint } \\
\text { of state }\end{array}$ & $E I+M I-S I \geq 0$ \\
\hline
\end{tabular}




\subsubsection{Fix FIP}

The essence of fix premium pricing is that the producer receives a market independent, predetermined premium, after its sales on the market. In this case the level of the subsidy is constant over the period, but the producer can achieve higher revenues, if he or she maximizes the volume and selling price of his sales (Fig. 3).

In the fixed premium system, the level of support remains unchanged by the entrepreneur's behavior, but sales revenue and operating costs can be changed. Thus, the relevance of the moral hazard assumption is:

$p_{H} M I-d_{H} C I+E I-I>0>p_{L} M I-d_{L} C I+E I+B I-I$ $p_{H} M-d_{H} C+E>1>p_{L} M-d_{L} C+E+B$.

In the optimization problem, sales revenues will be risky, so the objective functions will change. The generated energy is sold by the entrepreneur so the state's budget constraint extends only to the externalities of the project (as in the benchmark model) (Table 2).

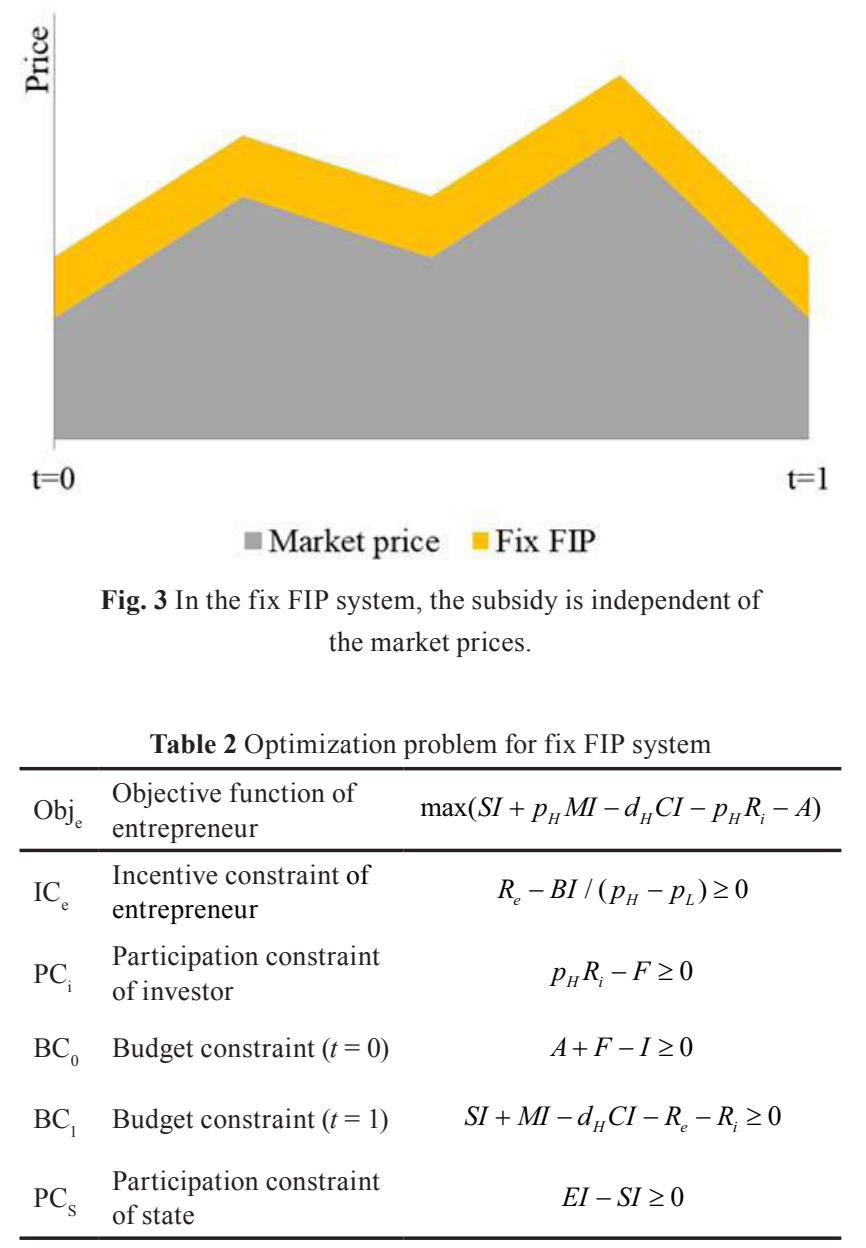

\subsubsection{Variable FIP with market reference price ("floating premium")}

While in the fixed FIP system, the entrepreneur received the same amount of support per unit of generated electricity, in variable premium pricing the premium rate is the difference between a fixed maximum subsidy ceiling and a reference price. As the reference price changes, the premium rate is also altered. A reference price can be the company's sales price or some other virtual price (for example, the average price for a fixed period of time for one of the products of the electricity market) (Couture and Gagnon, 2010). If the reference pricing is based on the sales of the company - without setting a cap and floor limit for prices - the producer will not be interested in maximizing its sales price in the support band and will converge towards the FIT from the perspective of the contractual terms. If the reference price is determined on a market basis (with the formation of a common virtual reference price) the producer will be motivated to maximize the sales price because the deviation $(\theta)$ from the market reference appears as a surplus or a cost (Fig. 4). Moreover, the operation of the system will be cheaper for the state as no separate reference price is required for each company.

We assume that the gap will be positive $(0 \leq \theta)$, so if the entrepreneur exerts a lot of effort, he or she can sell electricity over the market price, if the effort is low, then at worst the entrepreneur sells it at the electricity market (on the reference price). As the entrepreneur can obtain potential surplus income from the market, the private utility can be increased by not inducing state overpayments. In order to take into account the expected value of the sales gap $(\theta)$ in the social welfare, the revenue of the project should be corrected by the probabilities $p_{H}$ and $p_{L}$. The relevance of the moral hazard assumption in variable FIP with market reference price is:

$$
\begin{aligned}
& M I+p_{H} \theta I-d_{H} C I+E I-I>0 \\
& >M I+p_{L} \theta I-d_{L} C I+E I+B I-I \\
& M+p_{H} \theta-d_{H} C+E>1>M+p_{L} \theta-d_{L} C+E+B .
\end{aligned}
$$

In this model, besides the objective functions, the entrepreneur's incentive constraint also changes because the $\theta$ will reduce the agency costs. The assumption of this model framework is that the state is able to forecast and price the externalities and therefore does not handle the public risk while the level of subsidy varies. The market reference price variable FIP contract design optimization problem is shown in Table 3. 


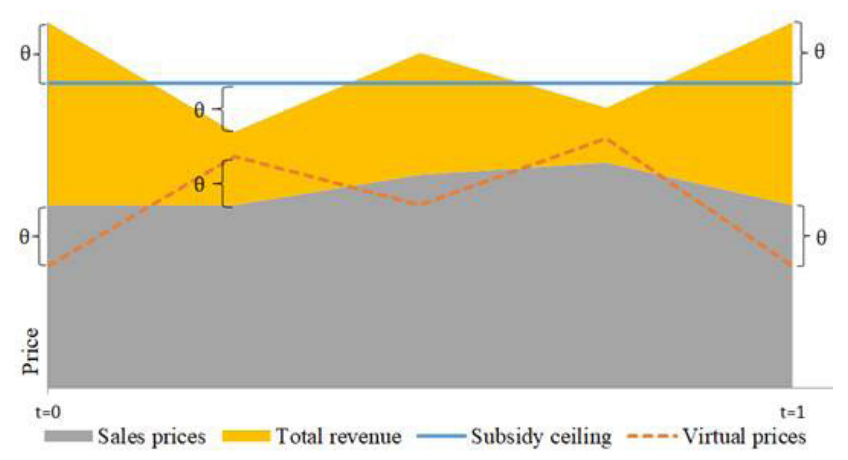

Fig. 4 In the floating premium system, additional sales profit can be achieved by increasing sales prices.

Table 3 Optimization problem for variable FIP system with market reference price

\begin{tabular}{clc}
\hline $\mathrm{Obj}_{\mathrm{e}}$ & $\begin{array}{l}\text { Objective function of } \\
\text { entrepreneur }\end{array}$ & $\max \left(S I+M I-d_{H} C I+p_{H} \theta I-p_{H} R_{i}-A\right)$ \\
\hline $\mathrm{IC}_{\mathrm{e}}$ & $\begin{array}{l}\text { Incentive constraint } \\
\text { of entrepreneur }\end{array}$ & $R_{e}-B I /\left(p_{H}-p_{L}\right)+\theta I \geq 0$ \\
$\mathrm{PC}_{\mathrm{i}}$ & $\begin{array}{l}\text { Participation } \\
\text { constraint of investor }\end{array}$ \\
$\mathrm{BC}_{0}$ & $\begin{array}{l}\text { Budget constraint } \\
(t=0)\end{array}$ \\
$\mathrm{BC}_{1}$ & $\begin{array}{l}\text { Budget constraint } \\
(t=1)\end{array}$ \\
$\mathrm{PC}_{\mathrm{S}}$ & $\begin{array}{l}\text { Participation } \\
\text { constraint of state }\end{array}$ & $A+F-I \geq 0$ \\
\hline
\end{tabular}

\subsubsection{Variable FIP with multiplier pricing}

In the case of multiplier pricing, the producer receives percentage of the sales price as a subsidy $(S I=\alpha M I)$. Overall, the disadvantage of this system is that it is difficult for the state to determine the volume of subsidies, but the advantage is that it rewards those participants who are more capable of selling their electricity, thus greatly contributing to the selection of producers and the integration of renewable technologies into the market (Fig. 5).

In multiplicative pricing, the entrepreneur's behavior affects everything (support, sales, costs), so he or she will be more motivated in this system to perform well and thereby increase profit. The new relevance of the moral hazard assumption is:

$$
\begin{aligned}
& p_{H} M I-d_{H} C I+E I-I>0>p_{L} M I-d_{L} C I+E I+B I-I \\
& p_{H} M-d_{H} C+E>1>p_{L} M-d_{L} C+E+B .
\end{aligned}
$$

In the optimization problem the subsidy will reduce agency costs and, as before, the objective functions and the budget constraint of $t=1$ will be modified (Table 4).

The regulators often use caps and floors in the FIP systems. The purpose of these is to ensure, that subsidies do

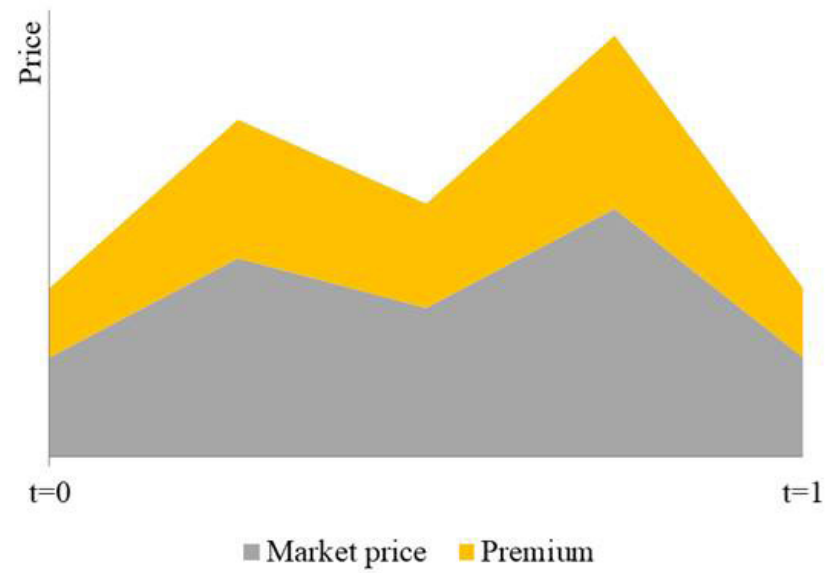

Fig. 5 In the multiplicative pricing system, the subsidy is a percentage of the sales price.

Table 4 Optimization problem for variable FIP system with

\begin{tabular}{|c|c|c|}
\hline $\mathrm{Obj}_{\mathrm{e}}$ & $\begin{array}{l}\text { Objective function of } \\
\text { entrepreneur }\end{array}$ & $\max \left(p_{H} M I(1+\alpha)-d_{H} C I-p_{H} R_{i}-A\right)$ \\
\hline $\mathrm{IC}_{\mathrm{e}}$ & $\begin{array}{l}\text { Incentive constraint of } \\
\text { entrepreneur }\end{array}$ & $R_{e}-B I /\left(\left(p_{H}-p_{L}\right)(1+\alpha)\right) \geq 0$ \\
\hline $\mathrm{PC}_{\mathrm{i}}$ & $\begin{array}{l}\text { Participation constraint } \\
\text { of investor }\end{array}$ & $p_{H} R_{i}-F \geq 0$ \\
\hline $\mathrm{BC}_{0}$ & Budget constraint $(t=0)$ & $A+F-I \geq 0$ \\
\hline $\mathrm{BC}_{1}$ & Budget constraint $(t=1)$ & $M I(1+\alpha)-d_{H} C I-R_{e}-R_{i} \geq 0$ \\
\hline $\mathrm{PC}_{\mathrm{S}}$ & $\begin{array}{l}\text { Participation constraint } \\
\text { of state }\end{array}$ & $E I-\alpha M I \geq 0$ \\
\hline
\end{tabular}
multiplier pricing

not increase drastically or if negative prices prevail, regulators will not pay for the subsidies. These boundaries can be modelled as a combination of the former systems, so the article does not deal with them in detail.

\section{Results}

The parameters that can be generated by solving the optimization problems are summarized in Table 5 and Table 6. The systems can be compared based on the size of investment $(I)$ and social welfare $(W)$. We define pledgeable income $\rho_{0}$ : the maximum expected income per unit of investment that the investor can provide without violating the incentives.

The social welfare of FIT and fix FIP can be described as Eq. (19) and Eq. (20):

$$
\begin{aligned}
& W=A\left(M-d_{H} C+E-1\right) \\
& /\left(1-\left(p_{H}\left(E+M-d_{H} C-\frac{B}{p_{H}-p_{L}}\right)\right)\right)
\end{aligned}
$$


Table 5 Results for decision parameters (FIT and Fix FIP)

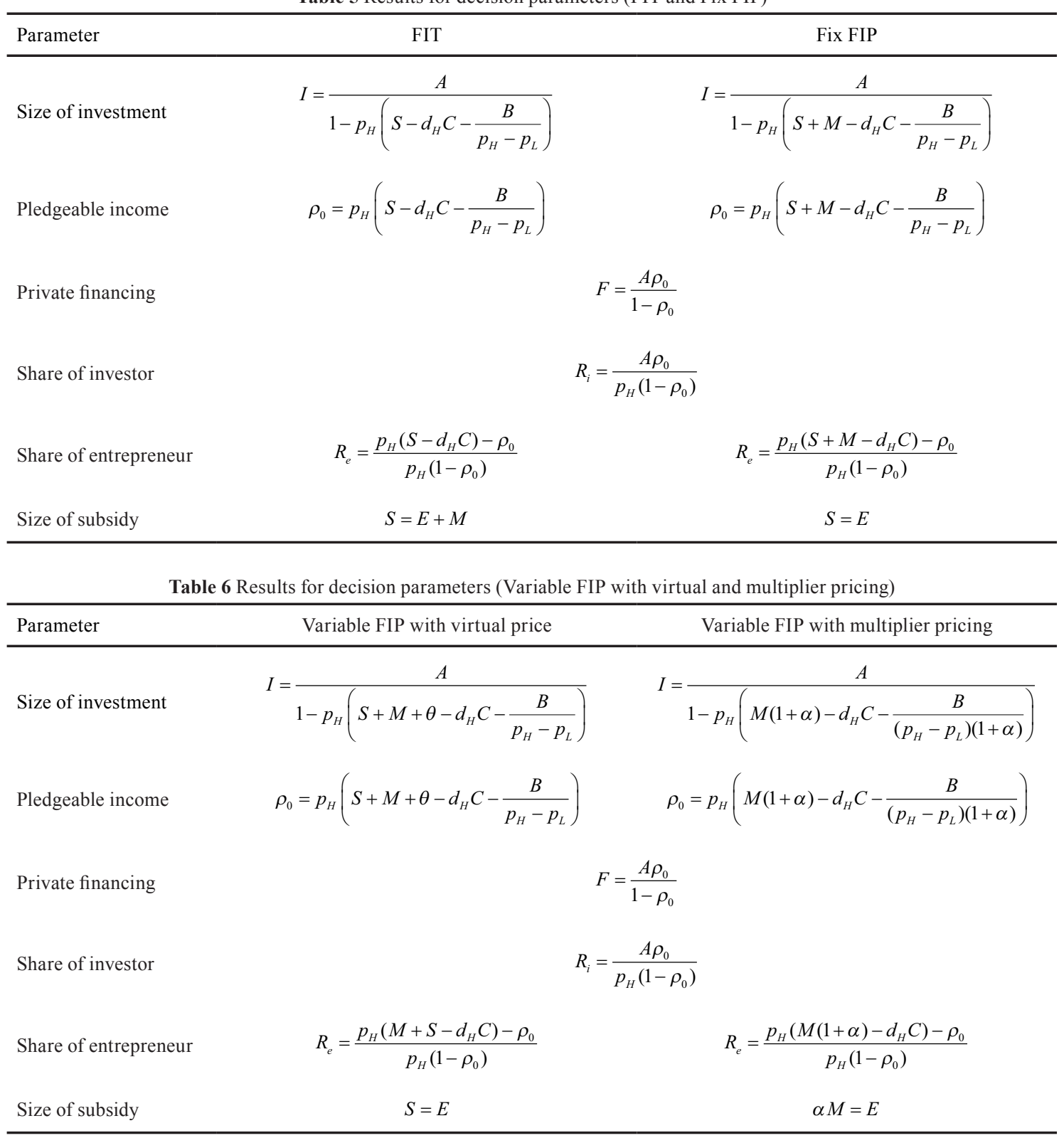

$W=A\left(p_{H} M-d_{H} C+E-1\right)$

$/\left(1-\left(p_{H}\left(E+M-d_{H} C-\frac{B}{p_{H}-p_{L}}\right)\right)\right)$.

The social welfare of variable FIP with virtual and multiplier pricing can be described as Eq. (21) and Eq. (22):

$W=A\left(p_{H} M+p_{H} \theta-d_{H} C+E-1\right)$

$/\left(1-\left(p_{H}\left(E+M+\theta-d_{H} C-\frac{B}{p_{H}-p_{L}}\right)\right)\right)$

$W=A\left(p_{H} M+p_{H} E-d_{H} C-1\right)$

$/\left(1-\left(p_{H}\left(M(1+\alpha)-d_{H} C-\frac{B}{\left(p_{H}-p_{L}\right)(1+\alpha)}\right)\right)\right)$.
The incentive constraint does not change in the FIT and fix FIP systems as compared to the benchmark model because these subsidies do not induce excessive motivation for entrepreneurs to do higher efforts. By contrast, the floating and multiplicative premium systems will facilitate the entrepreneur to encourage higher sales prices to increase his own payments. The amount of the subsidy is influenced by the sales that the investor can except, so the agency cost will be reduced.

The results clearly show that the smallest size of investment (and lowest pledgeable income) will be in the fix FIP system because the entrepreneur and the investor do not get compensation through by the subsidy system for the higher sales prices compared to the other models (if the state is able 
to sell electricity as efficiently as the contractor, the FIT and the fixed FIP have the same results). The most important achievement is that - even though the FIT subsidy is most secure from an investor point of view - the variable FIP with virtual price will be better than the FIT, because the entrepreneur becomes more motivated to maximize sales revenue, thus reducing agency costs, financing becomes more efficient, and size of investment increases, improving social welfare. The model also shows that this type of subsidy is well suited to the European Union's aspirations to integrate RES on the market, as investors will be interested in increasing $\theta$, and this can be achieved by better forecasting, operating smart systems, and portfolio optimization, all of which will help to drive renewables into the market.

Whether multiplier pricing will be better than FIT or variable FIP depends on the parameter $\alpha$. Following earlier assumptions the system does not affect the amount of subsidy paid (it is influenced by the externality), resulting in the following:

$\alpha=(S+M) /\left(p_{H} M\right)-1$.

As multiplier pricing increases sales motivation and reduces agency costs, this will also perform better than FIT. In the case of the determined value of the subsidy, the effectiveness of the motivation will decide, which premium system is the better: the extra profit available at a virtual price or the motivation for potential increase in subsidy. In reality there will be a margin at which the virtual price premium will be more favorable, but above certain volatility, multiplicative pricing will be more motivating.

\section{Conclusion}

The purpose of this article was to compare state support mechanisms for renewable electricity generation in terms of the level of information asymmetry that is emerging. The methodology used follows a well-known contract theoretical base model (Holmstrom and Tirole, 1997) and the extension of the state subsidy model (Berlinger et al., 2017), while partly retaining their assumptions. This paper looked at the behavior of three actors (an entrepreneur, an investor and the state) and described a model that shows how actors share the generated goods. It is important to clarify that the purpose of the article was not to clearly state that one of the subsidy schemes is generally superior than the other. The purpose of the model was to point out a factor that can be a single dimension of decision-makers' reflection and help actors better understand market processes to determine the ideal support system. The two most important assumptions used in this article was that the state is able to price accurately the externalities of the investment and pay it exactly as a subsidy, and the behavior of the entrepreneur can influence the operating costs and the sales revenue. If the motivation of the entrepreneur approaches the investor's motivation, the income that can be distributed between them will increase.

According to the built model, if the state is equally capable of selling electricity as a contractor and paying all these as subsidy, the feed-in tariff system and the fixed feed-in premium system are equivalent. However, if the support system adds an additional motivator that encourages the entrepreneur to sell better than other market participants, it reduces agency costs and thus increases the income of the entrepreneur and the investor. In the premium system, several pricing methods are suitable for introducing such motivations, this article dealt with floating, virtual premium pricing and multiplicative premium. In the model framework, both premium pricings decrease the agency costs and thus increase the private and social benefits of the projects.

The most important conclusion of this article is that support systems which provide less protection to the entrepreneur improve the efficiency of project funding through increased motivation. This generally contradicts the view that aid schemes offering more market protection are better for investors and points out that a reduction in market protection can be offset by increasing motivation, resulting in a reduction of agency costs.

To make the model presented in this paper more useful in energy policy decisions, it may be worthwhile to extend it to more criterions. The most important extension can be the presentation of different moral hazards that can be assigned to the different cost structures of renewable technologies. In cases where the hard-to-control operating costs are higher, the agency costs will be higher. A potential further development is a more detailed examination of the role of the state, which can be done on several levels. On one hand, the level of subsidies may be further sophisticated: taking into account that investments are subject to conditional (depending on the success of the investment) and unconditional (shown in the model) externalities. On the other hand, it may be worth testing the hypothesis that the support levels are the same because the state takes on a different risk in each subsidy system and this is affected by the tendering procedure for the support levels. An exciting addition could be that while projects compete for state subsidies, the state needs the timely completion of investments to reach its renewable energy commitments, but when the grant is awarded, the state has less information about the entrepreneur and this can lead to an adverse selection problem. 


\section{Acknowledgement}

The project presented in this article is supported by the ÚNKP-17-3-I New National Excellence Program of the Ministry of Human Capacities.

\section{References}

Ackerman, T., Andersson, G., Söder, L. (2001) "Overview of government and market driven programs for the promotion of renewable power generation", Renewable Energy, 22(1-3), pp. 197-204. https://doi.org/10.1016/S0960-1481(00)00015-X

Baker, G. P., Jensen, M. C., Murphy, K. J. (1988) "Compensation and Incentives: Practice vs. Theory", The Journal of Finance, 43(3), pp. 593-616.

https://doi.org/10.1111/j.1540-6261.1988.tb04593.x

Bebchuk, L. A., Fried, J. M. (2003) "Executive Compensation as an Agency Problem", Journal of Economic Perspectives, 17(3), pp. 71-92. https://doi.org/10.1257/089533003769204362

Berlinger, E., Lovas, A., Juhász, P. (2017) "State subsidy and moral hazard in corporate financing", Central European Journal of Operations Research, 25(4), pp. 743-770. https://doi.org/10.1007/s10100-016-0461-8

Bertrand, M., Mullainathan, S. (2000) "Agents with and without Principals", American Economic Review, 90(2), pp. 203-208. https://doi.org/10.1257/aer.90.2.203

Boscan, L., Poudineh, R. (2016) "Flexibility-Enabling Contracts in Electricity Markets", 1st ed., The Oxford Institute For Energy Studies, Oxford, UK.

Butler, L., Neuhoff, K. (2008) "Comparison of feed-in tariff, quota and auction mechanisms to support wind power development", Renewable Energy, 33(8), pp. 1854-1867. https://doi.org/10.1016/j.renene.2007.10.008

Chaney, P. K., Thakor, A. V. (1985) "Incentive effects of benevolent intervention: The case of government loan guarantees", Journal of Public Economics, 26(2), pp. 169-189. https://doi.org/10.1016/0047-2727(85)90003-9

Couture, T., Gagnon, Y. (2010) "An analysis of feed-in tariff remuneration models: Implications for renewable energy investment", Energy Policy, 38(2), pp. 955-965. https://doi.org/10.1016/j.enpol.2009.10.047

Csóka, P., Havran, D., Szűcs, N. (2015) "Corporate financing under moral hazard and the default risk of buyers", Central European Journal of Operations Research, 23(4), pp. 763-778.

https://doi.org/10.1007/s10100-013-0319-2

Dinica, V. (2006) "Support systems for the diffusion of renewable energy technologies - an investor perspective", Energy Policy, 34(4), pp. 461-480.

https://doi.org/10.1016/j.enpol.2004.06.014

Dinica, V. (2011) "Renewable electricity production costs-A framework to assist policy-makers' decisions on price support", Energy Policy, 39(7), pp. 4153-4167.

https://doi.org/10.1016/j.enpol.2011.04.021

European Parliament and Council Directive 2001/77/EC of 27 September 2001 on the promotion of electricity produced from renewable energy sources in the internal electricity market.
I would like to offer my special thanks to Péter Csóka, Mariann Szabó, Tamás Szőke, Szabolcs Vágvölgyi, Ákos Varga for their useful and constructive recommendations on this project.

European Parliament and Council Directive 2009/28/EC of 23 April 2009 on the promotion of the use of energy from renewable sources and amending and subsequently repealing.

European Commission Communication 2014/C 200/01 of 28 June 2014 on Guidelines on State aid for environmental protection and energy 2014-2020.

Fouquet, D., Johansson, T. B. (2008) "European renewable energy policy at crossroads-Focus on electricity support mechanisms", Energy Policy, 36(11), pp. 4079-4092. https://doi.org/10.1016/j.enpol.2008.06.023

Giacomarra, M., Bono, F. (2015) "European Union commitment towards RES market penetration: From the first legislative acts to the publication of the recent guidelines on State aid 2014/2020", Renewable and Sustainable Energy Reviews, 47, pp. 218-232. https://doi.org/10.1016/j.rser.2015.03.006

Greenwald, B. C., Stiglitz, J. E. (1986) "Externalities in Economies with Imperfect Information and Incomplete Markets", The Quarterly Journal of Economics, 101(2), pp. 229-264. https://doi.org/10.2307/1891114

Grossman, S. J., Hart, O. D. (1983) "An Analysis of the Principal-Agent Problem", Econometrica, 51(1), pp. 7-45. https://doi.org/10.2307/1912246

Hall, B. J., Liebman, J. B. (1998) "Are CEOs Really Paid Like Bureaucrats?", The Quarterly Journal of Economics, 113(3), pp. 653-691. https://doi.org/10.1162/003355398555702

Hart, O., Moore, J. (1998) "Default and Renegotiation: A Dynamic Model of Debt", The Quarterly Journal of Economics, 113(1), pp. 1-41. https://doi.org/10.1162/003355398555496

Hirsch, J. (2006) "Public Policy and Venture Capital Financed Innovation: A Contract Design Approach", Center for Financial Studies, Frankfurt am Main, Germany, CFS Working Paper No. 2006/29.

Holmstroöm, B. Tirole, J., (1997) "Financial ntermediation, Loanable Funds, and the Real Sector", The Quarterly Journal of Economics, 112(3), pp. 663-691. [online] Available at: http://www.jstor.org/stable/2951252 [Accessed: 01 February 2018]

Huntington, S. C., Rodilla, P., Herrero, I., Batlle, C. (2017) "Revisiting support policies for RES-E adulthood: Towards market compatible schemes", Energy Policy, 104, pp. 474-483. https://doi.org/10.1016/j.enpol.2017.01.006

International Energy Agency (2008) "Deploying Renewables: Principles for Effective Policies", [pdf] IEA Publications, Paris, France, Available at: https://www.iea.org/publications/freepublications/publication/DeployingRenewables2008.pdf [Accessed: 15 August 2018]

Keuschnigg, C., Nielsen, S. B. (2001) "Public Policy for Venture Capital", International Tax and Public Finance, 8(4), pp. 557-572. https://doi.org/10.1023/A:1011251920041 
Kleer, R. (2010) "Government R\&D subsidies as a signal for private investors", Research Policy, 39(10), pp. 1361-1374. https://doi.org/10.1016/j.respol.2010.08.001

Klein, A., Pfluger, B., Held, A, Ragwitz, M., Resch, G., Faber, T. (2008) "Evaluation of different feed-in tariff design options Best practice paper for the International Feed-In Cooperation", [pdf] Energy Economics Group, Fraunhofer Institute Systems and Innovation Research, Available at: file://C:/Users/user/ Downloads/best_practice_paper_2nd_edition_final\%20(1).pdf [Accessed: 15 August 2018]

Laffont, J.-J., Tirole, J. (1988) "The Dynamics of Incentive Contracts", Econometrica, 56(5), pp. 1153-1175. https://doi.org/10.2307/1911362

Lipp, J. (2007) "Lessons for effective renewable electricity policy from Denmark, Germany and the United Kingdom", Energy Policy, 35(11), pp. 5481-5495. https://doi.org/10.1016/j.enpol.2007.05.015

Mankiw, N. G. (2004) "Principles of Economics", 3rd ed., South-Western College Publishing, Nashville, USA.

Mendonça, M. (2007) "Feed-in Tariffs: Accelerating the Deployment of Renewable Energy", 1st ed., Routledge, London, UK. https://doi.org/10.4324/9781849771313

Nicolini, M., Tavoni, M. (2017) "Are renewable energy subsidies effective? Evidence from Europe", Renewable and Sustainable Energy Reviews, 74, pp. 412-423. https://doi.org/10.1016/j.rser.2016.12.032

Sappington, D. (1983) "Limited liability contracts between principal and agent", Journal of Economic Theory, 29(1), pp. 1-21. https://doi.org/10.1016/0022-0531(83)90120-5
Schertler, A. (2000) "The Impact of Public Subsidies on Venture Capital Investments in Start-Up Enterprises", Kiel Institute for the World Economics, Kiel, Germany, Kiel Working Paper No. 1018.

Schertler, A. (2002a) "Comparative Advantages of Public Loan and Public Equity Schemes in Venture Capital Markets", Kiel Institute for the World Economics, Kiel, Germany, Kiel Working Paper No. 1118.

Schertler, A. (2002b) "Venture Capitalists Investment Incentives Under Public Equity Schemes", Kiel Institute for the World Economics, Kiel, Germany, Kiel Working Paper No. 1117.

Shavell, S. (1979) "Risk sharing and incentives in the principal and agent relationship", The Bell Journal of Economics, 10(1), pp. 55-73. https://doi.org/10.2307/3003319

Stern, N. S. S. (2006) "The Economics of Climate Change", 1st ed., Oxford University Press, Oxford, UK.

Takalo, T., Tanayama, T. (2010) "Adverse selection and financing of innovation: is there need for R\&D subsidies?", The Journal of Technology Transfer, 35(1), pp. 16-41. https://doi.org/10.1007/s10961-009-9112-8

Tirole, J. (2006) "The Theory of Corporate Finance", 1st ed., Princeton University Press, Princeton, USA.

Verbruggen, A., Lauber, V. (2012) "Assessing the performance of renewable electricity support instruments", Energy Policy, 45, pp. 635-644.

https://doi.org/10.1016/j.enpol.2012.03.014 